International Journal of Social Sciences and Humanities
Available online at http://sciencescholar.us/journal/index.php/ijssh
Vol. 2 No. 3, December 2018, pages: 79 85
e-ISSN: 2550-7001, p-ISSN: 2550-701X
https://doi.org/10.29332/ijssh.v2n3.203

\title{
From the Individual to the Historical: A Commentary on Amitav Ghosh as a Writer of Historical Fiction with Reference to The Glass Palace
}

\author{
CrossMark \\ Neethi Mohan ${ }^{a}$, S.P. Suresh Kumar b \\ Article history: Received 21 April 2018, Accepted: 30 August 2018, Published: 4 October 2018
}

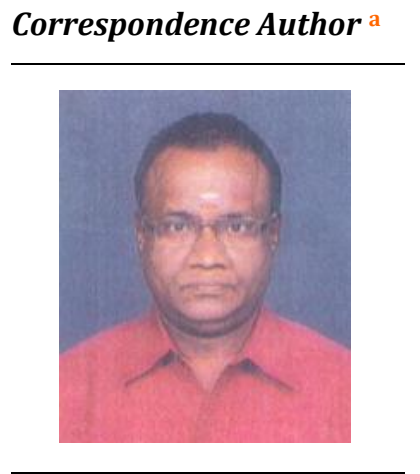

Keywords

Glass palace;

Historical fiction;

Identity;

Individual;

Self-explanation;

\begin{abstract}
Amitav Ghosh is widely known as a historical novelist in Indian Writing in English. He recreates the colonial past of the subcontinent from the colonized point of view. However, he is not one who merely recreates history. He is appreciated for writing history with life. He narrates the story of an individual who often turns out to be the representative of a community and its untold history. The Glass Palace is one such novel that recreates the history of the colonial past of India and Burma. The focus is mainly on the life of Rajkumar who is an Indian orphan struggling to survive in Burma after being unfortunately transported to the country by accident. This paper is an analysis of Ghosh's novel, The Glass Palace in order to show how the author recreates a lively history by narrating the life story of his protagonist.
\end{abstract}

e-ISSN: 2550-7001, p-ISSN: 2550-701X ${ }^{\odot}$ Copyright 2018. The Author. SS Journals Published by Universidad Técnica de Manabí. This is an open-access article under the CC BY-SA 4.0 license

(https://creativecommons.org/licenses/by-sa/4.0/) All rights reserved.

\section{Contents}

Abstract 79

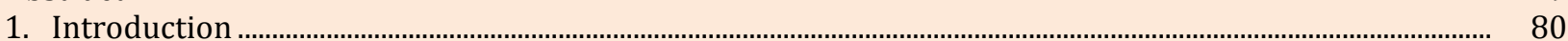

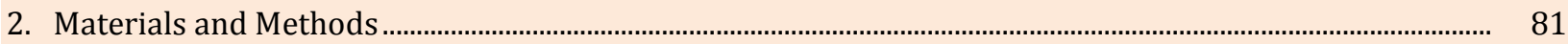

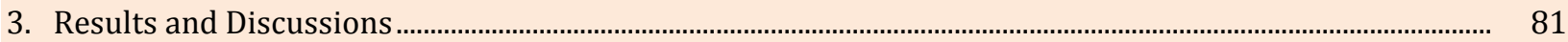

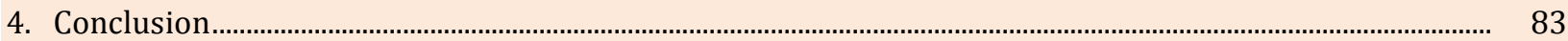

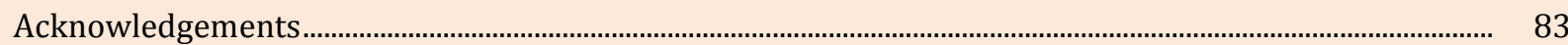

a Assistant, PSG Polytechnic College Coimbatore-641 004

b Associate Professor \& Head, Department of English, PSG College of Technology, Coimbatore-641 004 


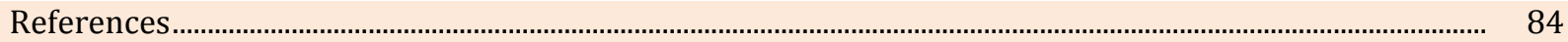

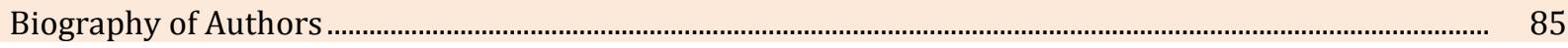

\section{Introduction}

Colonialism is one of the major events that impacted life in the subcontinent in all aspects including social, political, and cultural. However, the political establishment of the period did not record the plight of the oppressed; instead, it was keen on documenting history from its vantage point. This distortion was considered very significant that rewriting history by telling the untold stories became one of the primary objectives of the Post-Colonial movement. Amitav Ghosh is one such Post-Colonial writer, and his novel, The Glass Palace is one such Post-Colonial novel. By narrating the life story of an individual named Raj Kumar, Ghosh recreates the colonial history from the colonized point of view. Ghosh's concern is "not only with colonizer and colonized, but with both historical and contemporary relations between different colonized groups." (Skinner, 2002: 142)

Amitav Ghosh's The Glass Palace tells the untold stories of the then colonized and now independent countries India, Burma, and Bangladesh. The novel documents the impact of colonialism on the political, social, economic, and religious institutions of these countries. The novel is primarily set as a family saga spanning almost a century in time. Ghosh wants this novel as a historical fiction that recreates history through the narration of human stories. He also wants to show that human nature is the same throughout the world irrespective of the time, place, and race. The story encompasses the life history of two generations-the first generation, Rajkumar and Dolly, B.P. Dey and Uma; the second generation, Neel and Manju.

Ghosh, in this novel, weaves a saga of many stories and characters across generations and geographical boundaries. This novel is another evidence to strengthen the view that Ghosh is basically a humanist. The novel once again exemplifies Ghosh's purpose of writing: Voicing out against the oppression of politics. By narrating stories of individuals, Ghosh brings to light how imperialism affected the subcontinent. Problems of displacement, political instability, and social upheaval are given focus in this novel. Ghosh voices out against the oppression in the form of imperialism and colonialism. Ghosh dismisses power control in all forms including military, economic, and cultural. The novel shows how imperialism has badly impacted the colonies which are diametrically opposite to the discourse of the British. The novel also presents Ghosh's global vision for a borderless human community. By displacing the characters forcefully, Ghosh blurs the boundaries that demarcate nations and in turn identities. "When the dwelling place is uncertain, borders also compound the problem."(Dube, 2002: 93) and this compounding makes us realize that the boundaries are mere shadow lines.

Rajkumar is the protagonist of the novel. He is an Indian orphan who is accidentally deported to Burma. The very circumstance in which Rajkumar comes to Burma shows how the colonized individuals are treated more like objects by the rulers. The inconsiderate treatment given to Rajkumar, in the context of the atrocities committed in the name of imperialism, should be looked upon only as a mild and gentle treatment. However, Rajkumar is not destroyed by the displacement. Even though he does not know anyone in the new country, he is determined to survive. He represents the indomitable human spirit that urges individuals to withstand any form of cruelty and still come back as survivors and successful persons. In a way, Rajkumar is the representative of millions of the colonized people who struggle to survive against all odds.

The first part of the novel depicts how the British destroyed the lives of individuals as well as whole families without any compunction. The royal family was not an exception. Even though the king and the queen surrendered without any resistance, the British were indifferent to the plight of the royal family. They destroyed any moral and social decorum in the city that people, being reduced to the level of beasts, began to pillage and vandalize indiscriminately. The cruel reality is shown when the British army men were seen joining the looters. The protagonist Rajkumar was also seen among the looters. It was while looting the palace that Rajkumar met Dolly with whom he fell in love at first sight. 


\section{Materials and Methods}

Even though Rajkumar was new to Burma and did not have anyone to help him, he was confident of surviving. He was soon helped by a woman who owned a tea stall. He managed to get a job as well as food and shelter. Rajkumar began to live his life in a new country. Soon, he was helped by other people like Saya John. Being an intelligent and shrewd man, Rajkumar used all the help he could get and built a business for himself. The life and growth of Rajkumar as a businessman in Burma shows that individuals can survive in a new place in spite of displacements. It shows how the colonized people not only suffered under the colonizers, but they also learned to survive. Through the survival of Rajkumar in an alien land, one can see the universal goodness that prevails in every individual in spite of national, cultural, and social differences.

The innate quality to help others is present in every human being. It is evident even in Rajkumar's success in marrying Dolly, for whom he had been harnessing love for a long time. The intervention of the Collector's wife, Uma is one of the best examples of human kindness and its universality. Even though Dolly had some problems in marrying Rajkumar and moving with him to Burma, Uma helped the couple to get married. The marriage takes place between two persons - an Indian who lives in Burma as a businessman, and the other who is a Burmese living as a refugee in India.

Rajkumar, like most of his heroes, has an exploring nature. He is a good observer and a brave man who does not shy away from taking acceptable risks in life. Saya John, one of the characters in the novel, describes him as: "There was something unusual about the boy-a kind of watchful determination" (Ghosh, 2000: 30). The story of Rajkumar is that of a 'from-rags-to- riches' story. He begins working in a tea stall but soon climbs up the ladder in life. He is bold and brave. He is a worldly-wise character who tries to act older than what his actual age is. Throughout his life, he undertakes a quest for knowing people and places much like a traveler.

Rajkumar enters Burma as a boy. He explores the place with great enthusiasm and keen observation. However, he is destitute and he knows no one in the place. His keen observation allows him to understand people and their intention. For example, he knows well that Ma Cho would give him a job even though she shouts, "What do you think - I have jobs under my armpits, to pluck out and hand to you?"(Ghosh, 2000: 5).

Rajkumar is highly adaptive. In no time he develops a sense of belongingness to the place and the people. He has an incredibly positive attitude. He considers barriers as challenges. He wishes to have hurdles in his life so that he can break them and move ahead. He is adventurous and he willingly takes risks. His eagerness, intelligence and his positive attitude propel him into wealth and prosperity.

Rajkumar is a true hero in the sense that he began his life with nothing but ended up as a successful man with wealth, family, wife, and children. He did not miss any opportunity that came his way in life. He understood human beings: he sorted help from others and made friends. Though he remained as an uneducated orphan, he achieved success to some extent in life.

Rajkumar comes to Burma as a destitute and builds a life for himself. He is able to achieve success in life because he has the talent for understanding people and their intentions. Right from getting the work in the tea stall, to becoming a rich merchant, Rajkumar is successful because he observed people and fathomed out their thoughts. He met his wife in the palace when he was involved in looting it after it was captured by the British. It was a love at first sight, and he was determined in marrying her. In fact, he married her after a considerable struggle because she was involved in many problems.

\section{Results and Discussions}

Rajkumar is helped out by both men and women on many occasions. The woman in the tea stall, Ma Cho, who gave him his first job is the first of many to help him progress in life. Saya John, Macho's husband, also helps Rajkumar throughout his life. It is he who protects Rajkumar from the attackers: after the British rule was established in Burma, Burmese did not like Indians because they thought that Indians were shamelessly serving the cruel British. So, they were attacking and killing Indians who were in Burma, and who came to Burma. Rajkumar is also attacked on several occasions, and it is Saya John, who saves him every time. It is he who gives a job to Rajkumar in his factory. Saya John becomes a friend, philosopher, and guide to Rajkumar. He teaches him to survive as well as succeed in life. Rajkumar suffers his orphaned life, but he becomes

Mohan, N., \& Kumar, S. S. (2018). From the individual to the historical: a commentary on amitav ghosh as a writer of historical fiction with reference to the glass palace. International Journal of Social Sciences and Humanities, 2(3), 79-85. https://doi.org/10.29332/ijssh.v2n3.203 
stronger with John's guidance. "Rajkumar could tell that... But the pain lasted only an instant and when it had faded Rajkumar felt himself to be very much the stronger, better prepared" (Ghosh, 2000: 75) and he takes risks in life to develop his business. "If I am ever going to make this business grow, I will have to take a few risks" (Ghosh, 2000: 76). He takes risks and becomes a successful businessman. Later when Rajkumar decides to marry Dolly, he goes to Ratnagiri in India and finds her with the deported royal family. He faces many problems in marrying her, and it is Uma Dey, the wife of the collector who helps him out.

Misfortune strikes Rajkumar in his old age. He loses one of his two sons Neel who dies of health problems. Dinu, his other son, moves away from him. Devastated by the loss of their son, Dolly goes to a monastery. Rajkumar has an extramarital affair with a servant woman which results in the birth of Ilongo. Ghosh paints Rajkumar as an ordinary man with all the strengths and weaknesses. Rajkumar might have been the hero of the story who lives a successful life building it from rags to one of the richest businessmen in Burma, but he is not portrayed as a superhero by Ghosh. "The civilized rules of morality do not seem to work here as this novel is the true depiction of life. It is only quite natural for Rajkumar to succumb to his physical needs, with Dolly withdrawing into a world of her own. These events show that he continues to be an uneducated orphan." Rajkumar is undoubtedly a hero of an untold story, but he is as realistic as the next door neighbor businessman.

Human community is heterogeneous as it is a mixture of good and evil. Rajkumar was fundamentally good; he understood people, respected them, and made them his friends. So, there were friends for him even in a strange land. His life proves that a person can live anywhere, in any community under any circumstances, because human beings are fundamentally the same.

There is no boundary between India and Burma as far as Rajkumar is concerned. His life experiences have blurred the boundary between India and Burma for his individual self. Similarly, Dolly also proves that there can be life even across boundaries. Like Rajkumar was displaced from India to Burma, she was displaced from Burma to India. Yet, the love that they had for each other made them create a life together. Ghosh beautifully narrates this story in a realistic manner, allowing the same tone to deliver his concept of identity, nationality, and history - all are divided only by imaginary shadow lines.

Human beings are innately good. They have the natural tendency to bond with one another. They have many things in common, in spite of all the differences in culture, social systems, tradition, heritage, outlook, etc. These basic common human qualities present in every individual is that which makes Rajkumar seek a job from a totally unknown person Ma Cho, and it is the same quality that urges Ma Cho to employ Rajkumar. It is the same quality that enables John to recognize the good qualities in Rajkumar and help him. Because human beings are same everywhere, they are able to express and reciprocate all the basic emotions and feelings which is evident in various instances such as love between Rajkumar and Dolly, Dinu's attraction towards Addison. Such instances are seen in other novels of Ghosh as well. He creates these human interactions among his characters to reiterate the point that human beings are innately capable of coming together destroying all the imaginary boundaries created in the name of nationality.

Burma is as much a home as India to Rajkumar. Similarly, India would be considered as much a home as Burma by Dolly. Given enough time the temporal differences created by the extraneous factors would disappear allowing two individuals from two different backgrounds live together in a new environment. Some of the temporary differences between two individuals are created by the external factors such as political situations. The intervention of British in Burma is the primary cause for hostility between the Burmese and the Indians who went to Burma. Rajkumar was attacked by some of the Burmese because they thought that the Indians were indirectly responsible for the state of Burma becoming a colony under British rule.

However, in good or in bad, human beings are fundamentally the same everywhere. Ghosh strongly projects this point in the very beginning of the novel. When the Burmese surrendered to the British, the British ordered the king to surrender. They wanted the royal family to go in exile. When they complied with the British demand, people took this as an opportunity to loot the wealth in the palace. In looting, Ghosh shows that there is no difference between the British, Burmese, and even Indians. The Burmese servants and the public entered the palace and carried away all the precious objects.

The British soldiers who were responsible for safely taking the royal family into exile were also engaged in looting. Rajkumar was also involved in looting the palace. It was there he met his future wife Dolly, who was doing the job of taking care of the princess. Ghosh does not fail to show the noble qualities of people who are 
portrayed as looters and ruffians. He endorses the eastern concept of looking good in bad, and bad in good. He does not believe in the concept of binaries much like the western thought.

Ghosh narrates the life story of Rajkumar to show that national boundaries are imaginary lines that can be vanquished at the personal level. Elsewhere in his novels, he makes an attempt at extending this possibility to a whole community. As in the novel, Sea of Poppies, where he allows the passengers of an entire ship come together forgetting all the boundaries that hinder them towards establishing a society of no discrimination. The novel, The Glass Palace propounds the idea of disappearing national boundaries in the personal space of an individual.

\section{Conclusion}

The novel, The Glass Palace is more than a recreated historical fiction. It is a document that reiterates the point that individuals are capable of fighting for their survival in any circumstance. It also emphasizes the fact that human beings are innately good. By narrating history through an individual's story, Ghosh enlivens dry facts that cover the pages of history books. The following comments on The Shadow Lines are true for all his novels: "The overall story emerges in layers and each layer is a fusion of private lives and public events all linked into a thematic unity." (Kapadia, 2001: 85) He also tells the untold stories of the colonial era, thereby celebrating the heroes on the other side as well. The novel is an individual's life story of historical representation. Ghosh, in this regard, has created a unique genre for himself in the realms of Indian Writing in English. Yet, he is clearly descendent of his forerunners. "Ghosh develops a conscious and rich tradition in Indian English fiction -a tradition that includes R. K. Narayan and Shashi Deshpande." (Khair, 2001: 64) Ghosh's contribution to Indian Writing in English will always be valued for its worth.

\section{Acknowledgments}

The authors would like to thank the reviewer of the IJSSH as well as the editor of the IJSSH for their consideration, support, valuable time, and advice.

Mohan, N., \& Kumar, S. S. (2018). From the individual to the historical: a commentary on amitav ghosh as a writer of historical fiction with reference to the glass palace. International Journal of Social Sciences and Humanities, 2(3), 79-85. https://doi.org/10.29332/ijssh.v2n3.203 


\section{References}

Dube, P.D. (2002). Postcolonial Discourse in Amitav Ghosh's The Shadow Lines, Etd by Basavaraj Naikar. Indian English Literature. (Vol.1). Atlantic Publishers and Distributors.

Ghosh, D. (2016). Burma-Bengal Crossings: Intercolonial Connections in Pre-Independence India. Asian Studies Review, 40(2), 156-172.

Kapadia, N. (2006). The Metaphors of The Shadow Lines in Amitav Ghosh's Novel. Perspectives on Indian English Fiction, 256.

Khair, Tabis. (2001). "The Glass Palace by Amitav Ghosh", Wasafiri Reviews 64-67.

Skinner, J. (2002). Embodying voices: Language and representation in Amitav Ghosh's The Glass Palace. BELL. Belgian essays on language and literature, 137-149. 


\section{Biography of Authors}

\begin{tabular}{||l|l||}
\hline \hline & $\begin{array}{l}\text { Neethi Mohan is working at Assistant, PSG Polytechnic College, and Coimbatore- } \\
\text { India. He has published articles on writing by women of Canadian, Indian, and Sri } \\
\text { Lankan origin. He has published many research articles in various International } \\
\text { and national journals. He is also interested in Indian English novels and drama. } \\
\text { Email: neethimohan@gmail.com }\end{array}$ \\
\hline & $\begin{array}{l}\text { S.P. Suresh Kumar is employed as Associate Professor and Head of the } \\
\text { Department of English at PSG College of Technology, Coimbatore, Tamilnadu. His } \\
\text { areas of research include English and Indian Literature and Language Teaching, } \\
\text { and he is on the verge of submitting his doctoral thesis in Sri Aurobindo's poetry. } \\
\text { He has published nine research papers in International Journals so far and has } \\
\text { presented many papers at national and international conferences. } \\
\text { Email: suresh556@yahoo.com }\end{array}$ \\
\hline
\end{tabular}

Mohan, N., \& Kumar, S. S. (2018). From the individual to the historical: a commentary on amitav ghosh as a writer of historical fiction with reference to the glass palace. International Journal of Social Sciences and Humanities, 2(3), 79-85. https://doi.org/10.29332/ijssh.v2n3.203 